\title{
Gender Issues in Involuntary Resettlement due to Dam Construction: "Dam Brides" and the Tokuyama Dam in Japan
}

\author{
Shuichi Yamazawa ${ }^{1}$, Kanae Moriya ${ }^{1} \&$ Mikiyasu Nakayama $^{1}$ \\ ${ }^{1}$ Graduate School of Frontier Sciences, The University of Tokyo, Kasiwa, Japan \\ Correspondence: Shuichi Yamazawa, Graduate School of Frontier Sciences, The University of Tokyo, 5-1-5 \\ Kashiwano-ha, Kashiwa, Chiba 277-8563, Japan.
}

Received: January 29, 2018

Accepted: February 19, 2018

Available online: February 23, 2018

doi:10.11114/ijsss.v6i4.2954

URL: https://doi.org/10.11114/ijsss.v6i4.2954

\begin{abstract}
Many dams have been constructed around the world. Consequently, a great number of people have been displaced from their homelands by dam construction. These developments have tended to overlook gender differences. Thus, the resettlement process may exacerbate existing gender disparities in the communities affected by the project. Gender issues have seldom been studied in involuntary resettlements due to dam construction projects in Japan. This study was conducted about the Tokuyama dam, which has the largest storage capacity in Japan. Previous studies implicitly assume that all of the displaced people were originally from the submerged old Tokuyama village. Howe ver, our study revealed that some resettlers were in fact from outside of the old Tokuyama village. These were women called "dam brides" because they married men who were originally from Tokuyama, in the period immediately prior to the dam construction and subsequent resettlement. The men mostly met these "dam brides" in cities where they worked as seasonal workers in the winter. Knowing that the men would secure hefty compensation by leaving their homes in the old Tokuyama village, the "dam brides" decided to get married. They lived in the old Tokuyama village for only a few years before relocating to areas which were more "urban" than Tokuyama. These "dam brides," originally from cities, behaved differently after relocation than those from Tokuyama. They were keener to establish amicable relations with the people in the host community and were thus pivotal in accelerating the merging of the resettlers into their host community.
\end{abstract}

Keywords: resettlement, displaced persons, compensation, livelihood, gender

\section{Introduction}

\subsection{Gender Issues of Dam Construction}

Dams constructed around the world in the past obliged many people to resettle due to inundation of their homes. Various difficulties were reported in the re-establishment of their livelihoods after relocation. Cernea and McDowell (2000) classified the problems that displaced persons face into eight categories: landlessness, joblessness, homelessness, marginalization, morbidity, food insecurity, loss of access to common property assets, and social disarticulation. In addition, gender issues caused by displacement were also reported. Gender issues have been observed in several Asian dam construction projects. In the case of the Three Gorges Project in China, women were unable to get a new occupation after relocation due to discrimination against women and a lack of education (Tan, Hugo, \& Potter, 2005). In the case of the Bakun Hydro-electric Project in Malaysia, wives had no choice but to stay home, although their husbands went to the cities to earn money. Therefore, wives faced challenges in caring for their families in addition to securing food by planting crops. Moreover, women lost access to natural resources that provided food and craft materials in their original villages (Jehom, 2013). In the case of the Mahaweli Project in Sri Lanka, women were excluded from the right to own lands and their burden of women's role increased after resettlement because of the introduction of double cropping (Kumar, 1987). In the case of the Sardar Sarovar dam in India, a lack of water infrastructure in the resettlement area created particular problems for women. For example, women have to leave home to defecate outside before dawn or after dark because it is culturally unacceptable to be seen defecating (Sikka, 2016). These researchers suggest that gender differences were overlooked in the resettlement and livelihood re-establishment processes and that resettlement tends to exacerbate gender disparities that exist in project-affected areas.

\subsection{Problems of Dam Construction in Japan}

Hundreds of dams were constructed in Japan for agriculture, electricity generation, and disaster prevention during the 
rapid economic growth period after World War II, as shown in Figure 1. Consequently, huge numbers of people were obliged to leave their homelands because of dam construction.

Some Japanese researchers worked on the issue of resettlement due to dam construction. Hanayama (1969) surveyed 40 dams throughout Japan to suggest appropriate compensation schemes for displaced persons. He stressed the difficulty of livelihood re-establishment after displacement. Hanayama concluded that the compensation, provided only for property at that time, was insufficient and that more comprehensive supports were needed. After Hanayama's research, compensation schemes for resettlers gradually improved and the length of time for negotiations over dam construction between villagers and the dam constructor increased. Maruyama (1986) examined 14 dams throughout Japan, which were not included in Hanayama's survey. He found that displaced people's attributes diversified along with the economic development and that they tended to relocate to urban rather than rural areas. Therefore, he categorized submerged villages into three types (urban, rural, mountainous areas) and clarified the correlation between the three types of village and the length of negotiation for dam construction.

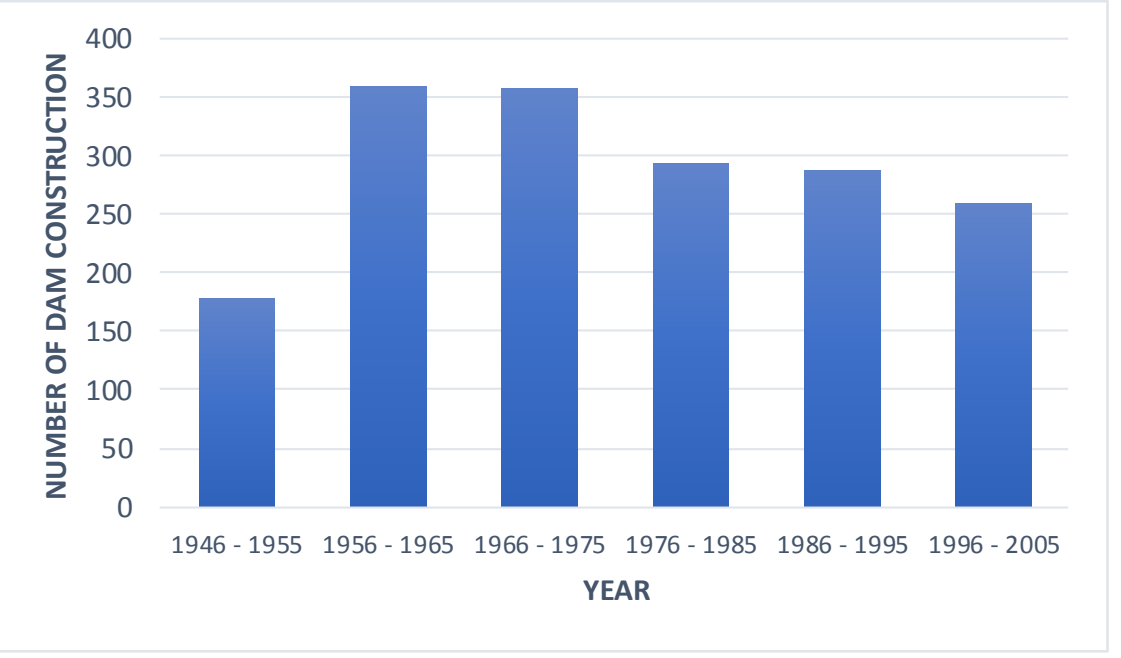

Figure 1. Number of dam construction projects by decade in Japan, 1946-2005. Developed by the authors based on Japan Dam Foundation (2016)

\subsection{Case Studies of the Tokuyama Dam}

We studied the Tokuyama dam in Gihu prefecture of Japan. The Tokuyama dam has the largest usage capacity among all the dams in Japan. Almost all the areas in the old Tokuyama village were submerged due to dam construction.

Very little research was ever conducted in Japan about gender issues related to resettlement by dam construction. Our first study revealed that there were not any gender issues which are similar to problems found in previous researches in other Asian countries. However, it became clear that there is a different type of gender issues in the case of the Tokuyama dam due to the presence of so-called "dam brides." "Dam brides" is the colloquial term given to women who do not originate from Tokuyama village, although they married men from there. It is natural that a bride starts to live in a husband's house after marriage in Japan. Therefore, "dam brides" shold be regarded as one of the gender issues which is peculiar to a patrilineal society. However, gender issues related to "dam brides" were not explored in the previous research on the Tokuyama dam. This may be because it was simply assumed that all the displaced persons were born and raised in Tokuyama. It may also be because in the previous research, intervie ws were carried out with the head of the household, who are in most cases men.

Kimura (1997) conducted follow-up surveys for more than 30 years of the resettlement process, from the period of negotiation until after resettlement, and identified the changes observed in Tokuyama village. Hamamoto (2001) found that people from Tokuyama suffered from emotional distress in three periods: a negotiation period, a livelihood re-establishment period, and a period of movement against dam construction in another city, which made displaced people think that the dam construction is useless. However, only monetary issues were discussed in the process of negotiating the resettlement.

Some researchers evaluated the long-term consequences of resettlement. Nakayama and Matsumoto (2016) analyzed the cases of the Tokuyama dam and the Miboro dam. They pointed out that these dams were developed in an era of very rapid economic growth in Japan and that prior to the resettlement the displaced persons had mostly been engaged in farming and forestry, without specific skills to secure new occupations after resettlement in urban areas. The authors also suggested that land-for-land compensation may not be the best option for resettlers because many of them wanted 
to relocate to urban areas and abandon farming as their major source of income. Sugiura and Matsumoto (2016) compared the case of Tokuyama with the Kusaki and Sameura dams. They showed the pattern of resettlement after displacement, which correlates with the degree of dependency on the productivity of the farmland.

As mentioned above, all the past research on the Tokuyama dam implicitly assumed that all the displaced persons originated from the now-submerged former Tokuyama village, which was not the case. Therefore, the objective of this study is (a) to verify the presence of "dam brides" among the persons displaced by the Tokuyama dam construction, (b) to find out whether there are observed differences in the behavior of "dam brides" vis-a-vis those originally from Tokuyama village, and (c) to figure out how the presence of "dam brides" in a community affects livelihood re-establishment after resettlement.

\section{Methodology}

We carried out surveys in August 2017 and November 2017. We interviewed a small sample of Tokuyama dam resettlers. Our interviewees included both men and women, whereas previous researchers preliminary interviewed the heads of households. In the first survey, 10 men and nine women were interviewed. In the follow-up survey, we interviewed one man and six women. Both surveys were undertaken in the resettlement areas of "Omoteyama," "Monjyu," and "Shibahara" under the condition that interviewees would be kept anonymous.

\section{Tokuyama Dam Construction and Resettlement of Residents}

The Tokuyama dam in Gihu prefecture is the largest multipurpose dam in Japan. It has a water storage capacity of 660 million tons. The dam was built by the Japan Water Agency on the Ibi River for the purposes of power generation, flood management, and industrial water supply. Figure 2 shows the location of the Tokuyama dam. A unique feature of the dam is that almost all lands in Tokuyama village were submerged and all 466 households (about 1500 people) had to move. Table 1 shows a timeline of Tokuyama dam construction.

The Japan Water Agency (JWA), owner of the dam, asked the resettlers either (a) to move to one of the five resettlement areas built by the JWA or (b) to move to a place of their own choice. Tokuyama village had been composed of eight hamlets. The villagers from these hamlets were "mixed" in the five resettlement areas of Omoteyama, Monjyu, Shibahara, Itonuki, and Amishiro, which were existing communities that already had residents. The lifestyle of the resettlers was completely changed after relocation. Before resettlement, villagers were mostly engaged in farming or forestry because the village was located deep in the mountain. After resettlement, about $40 \%$ of the family heads changed their occupation and about $60 \%$ of their spouses changed their occupation. The ratio of people engaging in farming or forestry dropped significantly, from $25.8 \%$ to $3.6 \%$ (Gihuken chihou jichi kenkyuu senta, 1988).

Table1.Timeline of Tokuyama dam construction

\begin{tabular}{ll}
\hline Year & \multicolumn{1}{c}{ Event } \\
\hline 1957 & Proposal of Tokuyama dam construction was announced at the firsttime. \\
1976 & The plan of Tokuyama dam construction was approved by Ministry of Construction. \\
1984 & Resettlement started. \\
1989 & All 466 households made a contract with Japan Water Agency. \\
2000 & The construction of Tokuyamadam started. \\
2008 & Tokuyama dam construction is completed. \\
\hline
\end{tabular}

Source: Developed by the authors based on Fujihashi-mura (1990). 


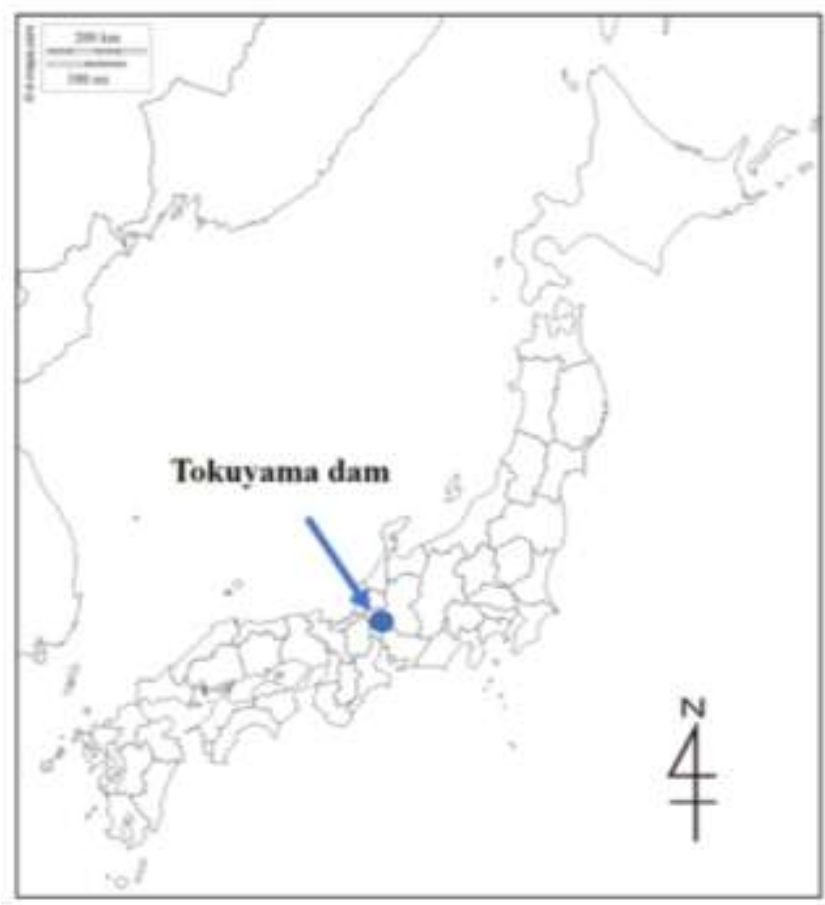

Figure 2. Location of the Tokuyama dam

\section{Findings}

\subsection{Outsiders}

Table 2 shows the change in population of Tokuyama village from 1955 to 1980. It should be noted that the rate of depopulation decreased in this period, even though many villages in Japan faced the problem of depopulation in the same period due to lack of opportunities for employment and education (Tokuyamamura, 1973). This indicates that people intended to stay in the village until they received compensation.

As Tanaka (1994) pointed out, outsiders who wanted compensation and who worked in Tokuyama village as doctors, teachers, and policemen, stayed in the village. Besides, throughout the interviews, it became clear that these people were aware that they were not "original" Tokuyama villagers. Thus, they did not relocate to the resettlement areas developed by the JWA, where almost all the Tokuyama villagers moved. Instead, the outsiders tended to move to big cities or relocate to other areas close to the developed resettlement areas.

We found that the resettlers included outsiders referred to as "dam brides." These are women, not originally from Tokuyama, who married men from the village. "Dam brides" decided to get married and live in the deep mountain area for only a few years before they would reloc ate from the village. About $20-30 \%$ of women in the old Tokuyama village were "dam brides" and the majority of these were from big cities such as Gihu and Nagoya (Anonymous, 2017a) (Anonymous, 2017b).

The "dam brides" met their husbands in big cities where the men had worked as seasonal workers in winter. These women told us that they were aware of hefty compensation to be given to their husbands, and this was the largest motivation for them to get married (Anonymous, 2017c). The "dam brides" tended to be regarded as money-chasers by the Tokuyama villagers. The nickname of "dam brides" was used in all the hamlets as a derogatory term.

It is natural that there were not only women who married for money, but also those who just fell in love with men from Tokuyama. Moreover, women who came from outside before the plan for the Tokuyama dam construction was officially approved and women who were married and moved to Tokuyama with their husbands for the purpose of negotiation should not, perhaps, be viewed as "dam brides"- the boundary between "dam brides" and other outsider women seems to be very vague. Howe ver, it is true that there were many outsiders who arrived in Tokuyama just before the dam construction and the subsequent move to the resettlement areas.

Our interviews also revealed that the "dam brides" had characteristics that were different from those of women who were originally from Tokuyama. "Dam brides" were not inclined to learn the history of Tokuyama and they did not try to understand the complicated kinship in the village (Anonymous, 2017a). 
Table 2. Population transition in Tokuyama village

\begin{tabular}{llllll}
\hline & Men & Women & Total Population & Household & Change in Total Population \\
\hline 1955 & 1208 & 1309 & 2247 & 428 & NA \\
1960 & 1243 & 1051 & 2294 & 482 & 47 \\
1965 & 977 & 905 & 1882 & 465 & -412 \\
1970 & 799 & 786 & 1582 & 455 & -297 \\
1975 & 701 & 745 & 1446 & 494 & -139 \\
1980 & 640 & 666 & 1306 & 511 & -140 \\
1985 & 303 & 329 & 632 & 179 & -332 \\
1990 & NA & NA & NA & NA & NA \\
\hline
\end{tabular}

Source: Ministry of Internal Affairs and Communications, National census (2005).

\subsection{Characteristics of "Dam Brides"}

\subsubsection{Opinion on Resettlement}

"Dam brides" are regarded as different from people originally from Tokuyama village, not only in terms of their birthplace, but also their characteristics. Those originally from Tokuyama tend to express their nostalgia for the now-submerged village. They also tend to express their dissatisfaction with other lifestyle and related changes, such as higher energy prices.

On the other hand, "dam brides" wished to leave Tokuyama as soon as possible. "Dam brides" tend to positively evaluate the resettlement in that they started participating in the activities of the host community, including shopping in the city which was never possible in Tokuyama. Some of the "dam brides" even mentioned that they felt relief from the mental stress caused by complicated and problematic human relations and customs in Tokuyama, such as participating in wedding ceremonies and funerals (Anonymous, 2017c). "Dam brides" felt unhappy about the lengthy negotiation process with the JWA regarding their resettlement because they wanted to leave Tokuyama as soon as possible. One "dam bride" informed us that she had assumed she would have to live in Tokuyama and endure the conventional lifestyle of the village for no more than a few years, although she eventually needed to stay there for more than 15 years (Anonymous, 2017d).

\subsubsection{Dissatisfaction with Infrastructure in the Resettlement Area}

As for opinions about the infrastructure in the resettlement area, differences were observed between the wi ves originally from Tokuyama and the "dam brides." Almost all the former were satisfied with the existing infrastructure such as transportation facilities, hospitals, and schools. These infrastructures were much more convenient and better than the ones in Tokuyama. In particular, schools provided resettlers with great benefits which could be enjoyed even by future generations of the displaced community.

In contrast, "dam brides" tended to be unsatisfied with the infrastructure in the host communities (Anonymous, 2017c). This may be because some of them had lived in big cities before marriage and they found the infrastructure in the host community inferior to that of big cities.

\subsubsection{Experienced to Work in Big Cities}

Many employment opportunities in construction works, including the Tokuyama dam construction, were available for resettlers due mainly to rapid economic growth in Japan at that time. Therefore, men from Tokuyama were able to find new occupations without major difficulties. Similarly, women from Tokuyama could find new occupations, especially part-time jobs in the city. However, some of them stressed that working in a city proved very hard for resettlers who were from deep in the mountain.

Some of "dam brides" seemed to be free from hardships in working after relocation. One "dam bride" we interviewed said that most women coming from outside had experiences in working part-time in big cities, whereas women from Tokuyama had never worked in cities. Another "dam bride" mentioned that one of the benefits of resettlement was that employment opportunities existed for women in the host (new) communities (Anonymous, 2017c).

\subsubsection{Relationship among Family Members}

Tokuyama villagers felt that their relationship with their children changed. As the resettlement area was located much closer to the big cities than the Old Tokuyama village, children working in cities were able to visit their parents' houses in the host community more easily than old Tokuyama village. Tanaka (1994) pointed out that the proportion of households with less than two family members declined from $50 \%$ before resettlement to $27 \%$ after relocation. This implies that displaced persons started living with their children who had jobs (and homes) in cities. Displaced persons thus felt happy with the new relationship with their children although they seldom met their children working in big cities before relocation. 
Similarly, "dam brides" found the resettlement area better than Tokuyama because of access to their parents' homes in the big cities. However, the relationship between "dam brides" and their mothers-in-law was problematic due to the differences in their cultural backgrounds. "Dam brides" from big cities did not understand Tokuyama culture which mother-in-law had. Therefore, tensions and conflicts led to some "dam brides" living separately from their mothers-in-law after resettlement (Anonymous, 2017e).

\subsubsection{Relations with Others before and after Resettlement}

Differences were observed between "dam brides" and others in establishing personal relationships, both before and after resettlement.

In Tokuyama, people had close relationships, especially with those in the same hamlet. They helped each other in rice farming and reconstruction of their houses, which is called "yui." People usually entered a neighbor's house without asking permission. The relationships among the villagers were much closer than those among people in the big cities. However, the "dam brides" did not have close relationships with their neighbors when they lived in Tokuyama. They preferred to be or talk with other "dam brides." Difficulty in mastering the dialect in the village and a lack of farming skills prevented "dam brides" from establishing good relationships with those who originated from Tokuyama (Anonymous, 2017a).

Tokuyama villagers lived in eight hamlets before resettlement. They moved to five resettlement areas established by the JWA where they had to interact and build relationships with resettlers who came from different hamlets than their own. They had to address two issues after relocation: (a) relationships with displaced persons from other hamlets, and (b) relationships with those in the host communities.

As for the former, people originally from Tokuyama tended to have close relationships only with those from the same hamlet. However, all the Tokuyama villagers interviewed mentioned that they had known each other before relocation and they experienced no difficulties in their interactions with those from other hamlets. "Dam brides" also tended to maintain relationships with the people from the same hamlet. In addition, "dam brides" had close relationships with other "dam brides" from the same hamlet.

As for relationships with people in host communities, people originally from Tokuyama seldom interacted with those in the host communities, whereas "dam brides" were keener to establish relationships with people in the host community. Participating in activities of the host community, such as cultural classes and volunteer works, enabled "dam brides" to interact with the host community. "Dam brides" interviewed informed us that the Tokuyama villagers were shy and they lacked experience in interacting with people in cities (Anonymous, 2017f). Tokuyama villagers tended to stay away from the host community due to their backgrounds being rooted deep in the mountains.

\section{Conclusion and Discussion}

Our survey made it clear that many outsiders moved to Tokuyama in anticipation of compensation, whereas previous research assumed that all the displaced persons were originally from Tokuyama. Moreover, the outsiders included "dam brides" who married men originally from the Tokuyama village with the intention of living in the village for just a few years before resettlement. Although the presence of "dam brides" was not revealed in previous research, this study showed the presence of this group and their characteristics. These characteristics can be explained in five categories. First, "dam brides" strongly agreed with resettlement. They tended to enjoy the new life after relocation to the host community, despite the difficulties Tokuyama villagers had in re-establishing their livelihoods in the new environment. Second, "dam brides" were not satisfied with the infrastructure in the resettled areas, which was inferior to the same in their hometown. Third, "dam brides" tended to find new occupations without difficulty after resettlement. Their work experiences in big cities before moving to Tokuyama proved useful for livelihood restoration in the host communities. Fourth, "dam brides" experienced difficulties in establishing good relationships with their mothers-in-law due to cultural differences between Tokuyama village and big cities. Finally, "dam brides" generally had a good relationship with people in the host community through communal activities, whereas original Tokuyama villagers rarely interacted with those in the host community.

\section{Acknowledgments}

This work was supported by JSPS KAKENHI Grant Numbers JP16H03320 and JP17K18590.The authors appreciate the great assistance of the Japan Water Agency in conducting the survey and are deeply grateful to resettled individuals who were willing to offer their precious time.

\section{References}

Anonymous. (2017a). Interviews by the authors with an anonymous community leader of the residents' association in a resettlement area, 24 November 2017. 
Anonymous. (2017b). Interviews by the authors with an anonymous man from the old Tokuyama village in a resettlement area, 26 November 2017.Anonymous. (2017c). Interviews by the authors with anonymous "dam brides" in resettlement areas, 24, 25, and 26 November 2017.

Anonymous. (2017d). Interviews by the authors with an anonymous "dam bride" in a resettlement area, 26 November 2017.

Anonymous. (2017e). Interviews by the authors with an anonymous man from the old Tokuyama village in a resettlement area, 22 August 2017.

Anonymous. (2017f). Interviews by the authors with an anonymous "dam bride" in a resettlement area, 26 November 2017.

Cernea, M. M., \& McDowell, C. (2000). Risks and reconstruction: Experiences of resettlers and refugees. Washington, D.C.: The World Bank. https://doi.org/10.1596/0-8213-4444-7

Fujihashi-mura [Fujihashi local office]. (1990). Tokuyama dam no kiroku [The history of Tokuyama dam]. Nagoya: Fujihashi-mura.

Gihuken chihou jichi kenkyuu senta [Local autonomy research center in Gihu prefecture]. (1988). Tokuyama damu. ijyuusha no sonogo [Displaced people by Tokuyama dam after resettlement], Jichiken gihu zoukan, 2.

Hamamoto, A. (2001). Koukyoujigyo minaoshi to tachinoki itensha no seishinhigai-Gihuken • Tokuyama damu Keikaku no jirei yori [Reconsideration of public works and emotional distress for displaced people - in the case of Tokuyama dam], Kankyoushakaigakukenkyu, 7.

Hanayama, Y. (1969). Hosho no Riron to Genjitsu [Compensation theory and reality]. Tokyo: Keiso shobo.

Japan Dam Foundation. (2016). Damu nenkan [Dam yearbook]. Tokyo: Japan Dam Foundation.

Jehom, W. J. (2013). Reconstruction of post-resettlement gender relations: The Kenyah-Badeng of Sungai Asap, Sarawak, Malaysia. Asian Journal of Women's Studies, 19(2), 122-147. https://doi.org/10.1080/12259276.2013.11666151

Kimura, K. (1997). Tamokuteki damu kaihatsu to Ibiya jyumin no henten ( II ) [Multipurpose dam construction and a change of Ibiya residents]. Mizushigen • Kankyo keikaku, 10, 60-66. https://doi.org/10.6012/jwei.1990.15

Kumar, S.P. (1987). The Mahaweli scheme and rural women in Sri Lanka. Women farmers and rural change in Asia: Towards equal access and participation. (220-253). Kuala Lumpur: Asia and Pacific Development Centre.

Maruyama, T. (1986). Damu hosho to suigen chiiki keikaku [Compensation for dam construction and a plan for water resource area]. Tokyo: Japan Dam Foundation.

Ministry of Internal Affairs and Communications. (2005) National census. Retrieved January 23, 2018, from https://www.e-stat.go.jp/stat-search/files?page=1\&layout=dataset\&toukei=00200521

Nakayama, M., \& Matsumoto, K. (2016). From deep in the mountains: The Miboro and Tokuyama Dams in Japan. Asian Journal of Environment and Disaster Management, 7(4), 321-332.

Sikka, G. (2016). The case of missing toilets in Sardar Sarovar dam resettlement in Vadodara, Gujarat. GeoJournal, 81, 257-266. https://doi.org/10.1007/s10708-014-9617-z

Sugiura, M., \& Matsumoto, K. (2016). Involuntary resettlement with differing degrees of dependency on farmland: The Tokuyama dam resettlement in Japan. Asian Journal of Environment and Disaster Management, 7(4), 359-372.

Tan, Y., Hugo, G. \& Potter, L. (2005). Rural women, displacement and the Three Gorges Project. Development and Change, 36(4), 711-734. https://doi.org/10.1111/j.0012-155X.2005.00431.x

Tanaka, S. (1994). Damu kensetsu ni tomonau setai no henka: Gihuken Ibi gun kyuu tokuyama mura no baai [Change of households due to a dam construction: In the case of old Tokuyama village in Ibi county, Gihu prefecture], Nippon Joumin Bunka kiyou, 17, 117-139.

Tokuyamamura. (1973). Tokuyamamurashi [Tokuyama history]. Gihu: Taishu shobou.

\section{Copyrights}

Copyright for this article is retained by the author(s), with first publication rights granted to the journal.

This is an open-access article distributed under the terms and conditions of the Creative Commons Attribution license which permits unrestricted use, distribution, and reproduction in any medium, provided the original work is properly cited. 